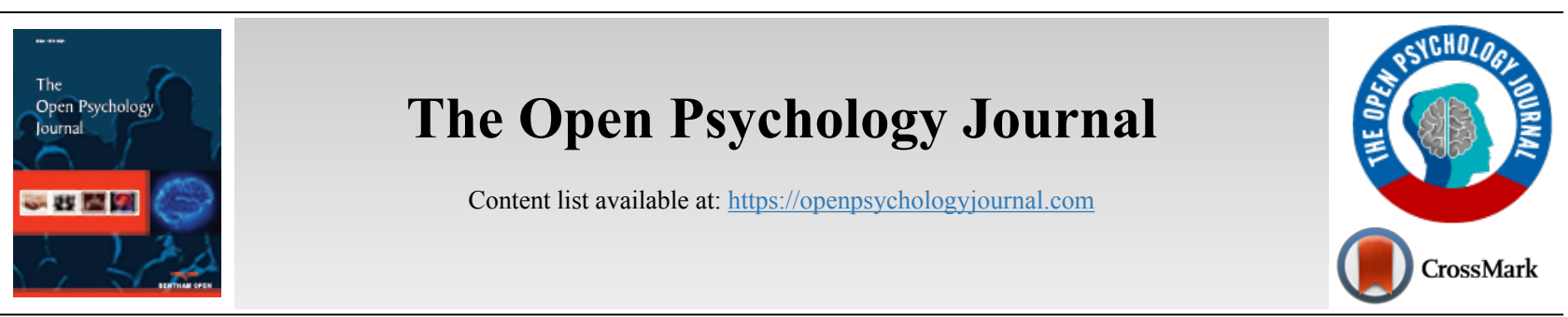

\title{
LETTER
}

\section{Ukrainian Translation and Linguistic Validation of the Gender Bias Quiz Questionnaire}

\author{
Tetiana Kostina, ${ }^{1, *}$, Diana Drozdova ${ }^{2}$ and Iryna Bulakh ${ }^{3}$ \\ ${ }^{\prime}$ Department of Psychology, Pereiaslav-Khmelnytskyi Hryhorii Skovoroda State Pedagogical University, 30, Sukhomlynskyi str., Pereiaslav, 08401, \\ Ukraine \\ ${ }^{2}$ Horlivka Institute for Foreign Languages of the State Higher Educational Institution «Donbas State Pedagogical University», 24, Vasily Pershin str., \\ Bakhmut, 84511, Ukraine \\ ${ }^{3}$ Department of Psychology, National Pedagogical University named after M. P. Dragomanov, 9, Pyrohova str., Kyiv, 01601, Ukraine
}

\begin{abstract}
:
This work aims to confirm the Ukrainian variant of the Gender Bias Quiz at a linguistic level. The questionnaire consists of 20 questions, which allows the psychologist to determine the individual's gender bias. Respondents (university students, 20-26 years old) completed the Ukrainian translated version of the Gender Bias Quiz questionnaire, and then two weeks later, students completed the original one. Statistical analysis of the data included the use of the Wilcoxon test and the Spearman correlation test. The Wilcoxon test results showed no significant differences between the original (English) and the translated questionnaire. Instead, the Spearman test showed a positive correlation at a high level of statistical significance between respondents' scores in the first and second tests. The obtained data proved the successful linguistic validation of this questionnaire.
\end{abstract}

Keywords: Gender bias, Linguistic validation, Questionnaire, Gender equality, Youth, Data.

Article History

Received: January 24, 2021

Revised: June 22, 2021

Accepted: July 17, 2021

\section{INTRODUCTION}

Nowadays, gender issues, identifying and analyzing existing gender stereotypes and beliefs are becoming topical all over the world. This type of study is of high importance to the development of society. So, a significant amount of scientists conduct research focusing on it. According to the Sustainable Development Goals provided by The United Nations (UN), gender equality is marked as goal number 5: achieve gender equality and empower all women and girls [1]. The main point highlighted in this document is that gender equality is not only a fundamental human right but a necessary foundation for a peaceful, prosperous and sustainable world [1].

The problem of gender equality has been peculiarly acute due to the COVID-19 pandemic. In particular, experts mention that during the lockdown, the number of domestic violence cases, in the vast majority, with women as victims has increased [2]. The World Health Organization emphasizes that pandemics and quarantine have led to serious consequences for women's health, especially in vulnerable groups [3].

\footnotetext{
Address correspondence to this author at the DDepartment of Psychology, Pereiaslav-Khmelnytskyi Hryhorii Skovoroda State Pedagogical University, 30, Sukhomlynskyi str., Pereiaslav, 08401, Ukraine; Tel: +38 0674794269;

E-mail: kostina.net@gmail.com
}

According to UN experts, the pandemic has negatively affected gender equality and exacerbated the problem. Areas with the greatest negative impact on women and, therefore, on gender equality include: economics (women, mostly earning less than men), health (increasing the cost of fighting the pandemic and as a result, reduction of health expenditures, in particular, reproductive), increase of workload for women in the field of unpaid care work, and increase of domestic violence-cases [4].

Also, the negative consequences of COVID-19 pandemic include lockdowns in the communities and countries and return of society to "traditional" values based on the stereotypical division of roles between women and men. According to established gender patterns, a woman should be engaged in reproductive work: caring for children, the elderly run. Such an approach to established gender patterns in society may reduce the achievements in the field of gender equality that have been made in recent decades [5].

The feminist movement present issues to rethink the role of women in society, which allowed them to expand their opportunities. For example, in most parts of the world, women have the right to vote, have access to education, and can move up the career ladder. Obviously gender equality is not just a 
"women's" problem. This is an issue that has an impact on men. For example, moving away from "traditional" gender roles allows men to be more sensitive and pay more attention to their families, to take an active part in raising children. Modern men have the right not to be "macho" and not to conform to established patterns of masculinity [6].

Representatives of the political and scientific community understand the need for greater involvement of women in decision-making, which is important for the further development of society [7,8]. More and more international organizations are realizing the need to support women's leadership. The important role of women in conflict prevention, peacebuilding and security in the world is emphasized [9].

It is emphasized that the absence of women in the public sphere has negative economic consequences [10, 11]. In addition, women's activity is important in the field of environmental issues. Scientists point out the need to take into account the gender component to increase the level of state environmentalism [12]. Studies in the field of gender issues have revealed the following connection: the higher the gender inequality in society, the lower the level of its environmental well-being [13]. In addition, the involvement of women in government contributes to improving the population's health [14]. Thus, there is a need to reduce gender inequality and involve more women in decision-making policy.

The ability of a person to go beyond established gender patterns is a necessary condition for establishing gender equality. That is why the study of gender equality should include the study of gender prejudices and stereotypes that exist in society. The analysis of the works of many authors (Allport, Bethlehem, Nelson, Jackson) showed that the issue of forming prejudices and stereotypes, including gender stereotypes, has a significant history [15 - 18]. Research shows that existing stereotypes are the basis for discriminatory actions against "others" [19].

Current psychological research in the field of gender issues demonstrates that a significant number of people no longer want to conform to established gender stereotypes and live by established rules for the distribution of gender roles. There are more and more people who want to go beyond gender roles and show their skills [20].

Moreover, there is a high level of gender bias and intolerance of gender equality in most former Soviet Union countries [21 - 26]. Hence, the study of attitudes is important for the development of a society where all people can realize themselves. At the same time, scientists from post-Soviet countries note that the study of gender stereotypes requires more attention from the scientific community.

What is more, one of the current interests is to study the impact of digital technologies on the formation and maintenance of gender biases. The analysis by Ege Gürdeniz \& Elizabeth St-Onge showed that even artificial intelligence technology has become a platform for spreading and supporting gender stereotypes [27]. Such results once again confirm the need to continue research that studies gender biases in society.

The study of gender biases is of particular importance for
Ukraine. It is worth noting that Ukraine shows positive changes in the issue of gender equality: the number of female deputies in the Verkhovna Rada, the Ukrainian parliament, has increased, the list of prohibited professions for women has been abolished, and Ukrainian men have been granted the right to go on maternity leave. However, statistics show that women are still underrepresented at the highest levels of government [21]. And the situation of the COVID-19 pandemic demonstrated the tendency of Ukrainian society towards the traditional distribution of gender roles and the growth of patriarchal attitudes. This situation actualizes the issue of studying gender biases of Ukrainians. Thus, the study of gender attitudes of Ukrainian youth has great importance. Due to the fact that young people will influence the political and social situation in the country in the near future.

Therefore, it is crucial to understand the specifics of young people's attitudes to sensitive public topics. One of these topics for Ukraine is the topic of gender equality that is why our research is devoted to the study of gender stereotypes of student youth.

\subsection{Methodology Review}

According to the methodology of psychological research, the study of any psychological phenomenon should be provided with adequate methodological tools: reliable and valid tests and questionnaires [28]. This approach allows the researcher to be sure of the reliability of the data obtained during the use of the tool.

At present, special tests and questionnaires are used in the field of gender issues. One of the first and most popular in psychological science was a questionnaire to determine the gender type of personality, developed by S. Bem - The Bem Sex-Role Inventory (BSRI) [29]. This questionnaire does not lose its relevance today. It is important for us that the Bem Sex-Role Inventory has been translated into Ukrainian language and passed the standardization procedure so that it can be used in the Ukrainian sample. However, current research suggests that this questionnaire needs to be revised and modified, as the current view of female (femininity) and male (masculinity) traits differs from the prevailing notions of the 1980 's of the 20th century [30,31]. This means that modern psychology needs other methods to determine the gender type of personality.

The need to identify unconscious social attitudes, including gender biases, led to the development of the Implicit Association Test (IAT), which is also called Hidden Bias Tests [32]. The presence of the term "implicit" in the title of this test emphasizes that it works with unconscious settings and uses an indirect mechanism to measure them. For this reason, identification of the presence/absence of gender stereotypes occurs on the basis of an analysis of average indicators of reaction rate to the information that is demonstrated to the subject. One of the disadvantages of IAT is: it is not available in Ukrainian language, which makes it difficult to use it in scientific research in Ukraine. The other disadvantage is that the Implicit Association Test (IAT) requires specialized software. This means that the procedure of translation and adaptation of the test is not limited to psychological and 
statistical procedures. This is evidence that the procedure is quite complex, and implementing this type of test requires a lot of resources.

One of the most commonly used questionnaires in psychological science to study gender stereotypes of personality is the Gender Bias Quiz. This questionnaire was developed and published in Canada in 2015 with the support of the intergovernmental organization The Commonwealth of Learning (COL) [33]. The advantage of this questionnaire is that it determines the level of gender bias of the person. In general, there are four categories that indicate a certain level of presence of gender biases: from low to high levels of severity of gender biases. The disadvantage of the Gender Bias Quiz is that the respondents can "adjust" their own answers to questions in accordance with social expectations. Thus, the results would not indicate what the respondent really thinks but what he/she wants others to think about him/her. However, this remark applies to all explicit techniques used in psychological research. Because, in contrast to the implicit, explicit methods work at the level of conscious material and are usually used in the form of a survey (oral or written) [34]. Thus, the study of gender biases should be combined with implicit methods such as the Implicit Association Test (IAT).

It should be noted that the Gender Bias Quiz questionnaire does not require additional software and can be applied immediately after the appropriate standardization and validation procedure. Unfortunately, in Ukraine only the Bem Sex-Role Inventory has been translated into Ukrainian. There are other tests and questionnaires, but they are mostly presented in the Russian language. The peculiarity of Ukrainian society is that many people speak Russian, which was the basic language during the Soviet Union. However, the modern socio-political development of the Ukrainian state confirms the need to use methods that are presented in the state language - Ukrainian. So, it's an urgent necessity to introduce
Ukrainian-language psychological methods in Ukrainian society.

That is why the aim of this research is to produce a semantically equal Ukrainian variant of Gender Bias Quiz questionnaire. It is worth emphasizing that the linguistic validation of the translation of the questionnaire is the first step for further determining the psychometric properties of the translated version of the instrument for use in a sample of young people (students) of Ukraine. The Ukrainian variant of the questionnaire can be used to study the characteristics of gender stereotypes of Ukrainian youth.

It should be noted that permission to translate and use this questionnaire was implemented in accordance with the regulation "ITC Statement on the Use of Tests and Other Assessment Instruments for Research Purposes", which was developed by the International Test Commission [35]. According to this regulation, scientists and researchers may use tests and other materials in the public domain without the author's permission. In particular, researchers have the right to translate tests or parts thereof. Nevertheless, the researcher should acknowledge the authors and publication source when reporting their findings.

The theoretical analysis of the requirements for the translation and adaptation of questionnaires allowed us to create a conceptual model of the study (Fig. 1) [36 - 38]. The process of adapting the Gender Bias Quiz questionnaire for the Ukrainian population was implemented according to this conceptual model. It is worth noting that in this article, we present the results of linguistic validation of the Gender Bias Quiz questionnaire in Ukrainian. Therefore, in the presented study, we examine whether our proposed Ukrainian-language version of the questionnaire can be used to study the gender biases of Ukrainians. The results of the standardization of the questionnaire, where we checked its reliability, are presented in our other scientific article, which was reviewed in another scientific journal and accepted for publication.

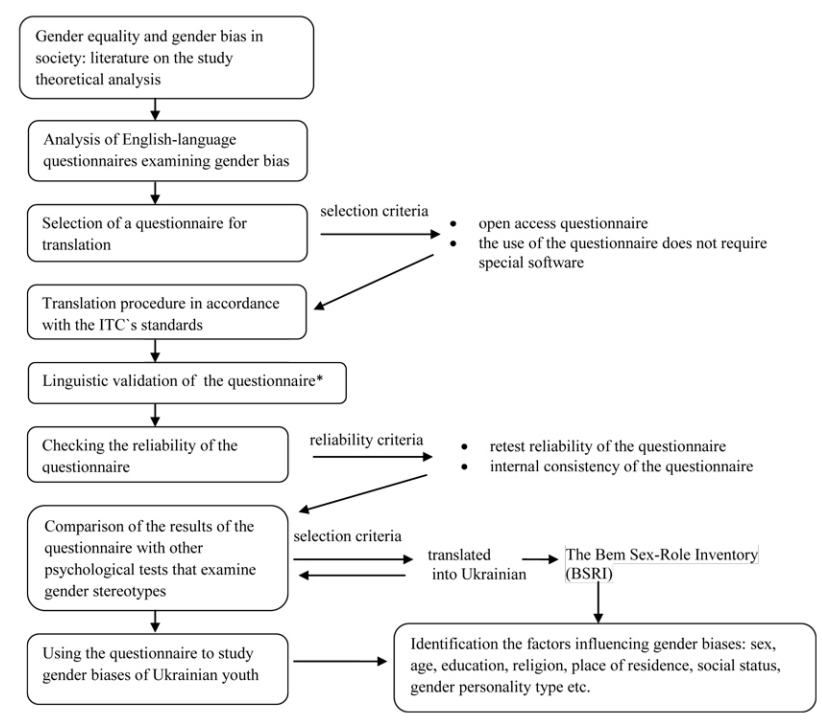

Fig. (1). Conceptual model of the study: adaptation of the Gender Bias Quiz questionnaire to study gender biases of Ukrainian youth. Note* the linguistic validation results are presented in this article. 


\section{MATERIAL AND METHODS}

\subsection{Participants and Procedure}

The translation procedure of the questionnaire was carried out in accordance with international standards. In particular, we relied on the recommendations of The World Health Organization and the International Test Commission [39, 40]. According to the recommendations, the translation of the questionnaire took place in several stages. The first stage included the translation of the questionnaire from English into Ukrainian. The translation was done by two Ukrainian translators. As a result, two versions of the direct translation of the questionnaire (from English to Ukrainian) were obtained. A working group of experts, consisting of three scientists working in the field of psychology, reviewed and adjusted the translation.

After the translation was approved by a working group of psychologists, the Ukrainian translator, who did not translate the questionnaire at the previous stage, translated the Gender Bias Quiz questionnaire back into English. The next round included the process of de-centering the questionnaire. It was provided by comparing the questionnaire translated in backorder with the questionnaire's original version. Subsequently, the Ukrainian version was improved by a group of experts, focusing on the clarity of the translated materials.

Before the final approval of the questionnaire's translation, participants filled in the translated Ukrainian version of the questionnaire, additional comments on the wording were made, and the final version of the Ukrainian version was finally approved. At the pre-test stage of the survey, 51 Ukrainian respondents took the Ukrainian version of the Gender Bias Quiz.

Following the requirements for the translation of questionnaires, respondents must complete the original and translated variants of the instrument after a certain period of time. In most cases, this interval should approximately from two to four weeks. In our study, respondents took the original (English) version of the questionnaire two weeks after completing the Ukrainian variant. It should be noted that 46 respondents completed both versions of the questionnaire, although the initial number of respondents was 51. At the beginning of the study planning, the possibility of reducing the number of participants was mentioned, so decreasing the sample was not crucial for the results of the study.

A pilot study of the instrument (Gender Bias Quiz) was conducted on Ukrainian students studying in higher education institutions aged from 20 to 26 years $(\mathrm{M}=21.52, \mathrm{SD}=1.49)$. Region of research: Kyiv (Ukraine). To guarantee a satisfactory level of respondents' English proficiency, a sample of the study was formed based on relevant indicators. The research involved philology students who study English Philology and have high academic proficiency.

The other part of the sample consisted of Master's Program students. They took an English proficiency test and have shown sufficient language proficiency (this is a prerequisite for studying for a master's program in Ukraine). The predominant number of respondents were female $(\mathrm{N}=32)$. Participators performed a paper variant of the questionnaire. All participants provided informed consent before participating in the study. A detailed description of the sample was reported in Table $\mathbf{1}$.

Table 1. An itemized response sheet.

\begin{tabular}{|c|c|c|c|c|}
\hline No of participant & Sex & Age & Test1 (total score) & Test2 (total score) \\
\hline 1 & female & 22 & 42 & 49 \\
\hline 2 & female & 22 & 35 & 28 \\
\hline 3 & female & 21 & 37 & 33 \\
\hline 4 & female & 23 & 36 & 30 \\
\hline 5 & female & 23 & 35 & 30 \\
\hline 6 & female & 22 & 41 & 39 \\
\hline 7 & female & 23 & 29 & 28 \\
\hline 8 & female & 23 & 37 & 48 \\
\hline 9 & female & 21 & 36 & 42 \\
\hline 10 & female & 20 & 43 & 26 \\
\hline 11 & female & 20 & 33 & 32 \\
\hline 12 & female & 23 & 34 & 31 \\
\hline 13 & female & 21 & 34 & 42 \\
\hline 14 & female & 20 & 41 & 52 \\
\hline 15 & female & 21 & 53 & 49 \\
\hline 16 & female & 20 & 42 & 31 \\
\hline 17 & female & 22 & 35 & 21 \\
\hline 18 & female & 22 & 37 & 33 \\
\hline 19 & female & 21 & 36 & 30 \\
\hline 20 & female & 23 & & \\
\hline 21 & female & 22 & & \\
\hline
\end{tabular}




\begin{tabular}{|c|c|c|c|c|}
\hline 22 & female & 23 & 35 & 30 \\
\hline 23 & female & 23 & 41 & 39 \\
\hline 24 & female & 23 & 29 & 28 \\
\hline 25 & female & 21 & 37 & 48 \\
\hline 26 & female & 20 & 36 & 29 \\
\hline 27 & female & 23 & 43 & 42 \\
\hline 28 & female & 20 & 33 & 26 \\
\hline 29 & female & 21 & 34 & 32 \\
\hline 30 & female & 20 & 34 & 31 \\
\hline 31 & female & 20 & 41 & 42 \\
\hline 32 & female & 21 & 53 & 52 \\
\hline 33 & male & 20 & 63 & 67 \\
\hline 34 & male & 21 & 23 & 26 \\
\hline 35 & male & 20 & 40 & 42 \\
\hline 36 & male & 20 & 43 & 47 \\
\hline 37 & male & 26 & 34 & 35 \\
\hline 38 & male & 21 & 66 & 56 \\
\hline 39 & male & 22 & 49 & 52 \\
\hline 40 & male & 21 & 63 & 67 \\
\hline 41 & male & 20 & 23 & 26 \\
\hline 42 & male & 20 & 40 & 42 \\
\hline 43 & male & 26 & 43 & 47 \\
\hline 44 & male & 20 & 34 & 35 \\
\hline 45 & male & 22 & 66 & 56 \\
\hline 46 & male & 21 & 49 & 52 \\
\hline $\mathrm{N}=46$ & female $=32 ;$ male $=14$ & $\mathrm{M}=21.52 ; \mathrm{SD}=1.49$ & $\mathrm{M}=39.65 ; \mathrm{SD}=10.08$ & $\mathrm{M}=38.61 ; \mathrm{SD}=11.45$ \\
\hline
\end{tabular}

\subsection{Measures/Questionnaire}

Gender Bias Quiz questionnaire is a 20-item instrument that measures a person's gender biases. Respondents read the statements in the questionnaire and answer, estimating how much they agree/disagree with each statement of the questionnaire. This rating is based on a four-point Likert scores ranging format: 1 = completely disagree, 2 = somewhat disagree, $3=$ somewhat agree, $4=$ completely agree.

Instructions and examples are provided by the authors, explaining that respondents should evaluate each statement, taking into account how much they agree with this statement (from 1 point to 4 points). After the participants confirmed their understanding of the instructions, the testing procedure began.

\subsection{Statistical Analysis}

Statistical analysis of the obtained data was performed using The IBM SPSS Version 23.0. Relevant statistical criteria were used to verify the correctness of the linguistic validation of the Ukrainian-language variant of the questionnaire. First, the equivalence of two versions of the questionnaire was checked: the original English version and the variant that was presented in Ukrainian. An indicator of successful linguistic validation is the absence of a difference in these two samples' average values (medians). We chose a non-parametric statistical criterion for checking whether medians significantly differ among the questionnaire's two variants - the Wilcoxon test. This statistical test was chosen because the number of subjects is not large enough to apply parametric criteria (e.g., Student's t-test).

Spearman's correlation was used to determine the relationship between the original and the translated variants of the questionnaire. This statistical criterion allows describing the relationship between two variables using a monotone function. This type of correlation also allows the calculation of the data presented on the ordinal scale. As this questionnaire's statistical standardization has not yet taken place, this is evidence that the data obtained belong to the ordinal scale. The collected results were interpreted by the rules specified in the scientific literature [41, 42].

\section{RESULTS}

At the beginning of the statistical analysis, the mean scores for both English and Ukrainian translated variants of the Gender Bias Quiz questionnaire were calculated. The mean reached $38.61(\mathrm{SD}=11.45)$ for the Ukrainian translated version, while for the English version, $M=39.65$ ( $D=10.08)$.

Subsequently, the Wilcoxon test was applied $(Z=-1.529$, $\mathrm{p}=0.126$ ), which showed no statistically significant difference between the results of the first test (the original version of the questionnaire) compared to the second test results (Ukrainian version). The applied statistical analysis showed that the translation does not distort the respondents' answers. A detailed description of the results is reported in Table $\mathbf{2}$ 
Table 2. The results of the Wilcoxon test for the Gender Bias Quiz questionnaire.

\begin{tabular}{|c|c|c|c|c|}
\hline \multicolumn{5}{|c|}{ Ranks } \\
\hline & & $\mathrm{N}$ & Mean Rank & Sum of Ranks \\
\hline \multirow[t]{4}{*}{ Test1 - Test2 } & Negative Ranks & $18^{\mathrm{a}}$ & 22,28 & 401,00 \\
\hline & Positive Ranks & $28^{b}$ & 24,29 & 680,00 \\
\hline & Ties & $0^{c}$ & & \\
\hline & Total & \begin{tabular}{|l|}
46 \\
\end{tabular} & & \\
\hline \multicolumn{5}{|l|}{$\begin{array}{l}\text { a. Test } 1<\text { Test } 2 \\
\text { b. Test } 1>\text { Test } 2 \\
\text { c. Test } 1=\text { Test } 2\end{array}$} \\
\hline \multicolumn{5}{|l|}{ Test statistics ${ }^{a}$} \\
\hline & & \multicolumn{3}{|c|}{ Test1 - Test2 } \\
\hline \multicolumn{2}{|c|}{$\mathrm{Z}$} & \multicolumn{3}{|c|}{$-1,529^{b}$} \\
\hline \multicolumn{2}{|c|}{ Asymp.Sig (2-tailed) } & \multicolumn{3}{|c|}{,126 } \\
\hline
\end{tabular}

The second step was a Spearman correlation test between the translated and the original scores of the questionnaire. Statistical analysis showed a high, positive monotonic correlation between pre- and post-test scores $\left(\mathrm{r}_{\mathrm{s}}=0.91\right.$, $\mathrm{p}<0.001)$. A detailed description of the results is reported in Table 3.

Table 3. Correlations for the Gender Bias Quiz questionnaire.

\begin{tabular}{|c|c|c|c|c|}
\hline \multicolumn{5}{|c|}{ Correlations } \\
\hline & & & Test1 & Test2 \\
\hline \multirow[t]{6}{*}{ Spearman`s rho } & \multirow[t]{3}{*}{ Test1 } & Correlation Coefficient & 1,000 &, $913^{* *}$ \\
\hline & & Sig. (2-tailed) & & ,000 \\
\hline & & $\mathrm{N}$ & 46 & 46 \\
\hline & \multirow[t]{3}{*}{ Test2 } & Correlation Coefficient &, $913^{* *}$ & 1,000 \\
\hline & & Sig. (2-tailed) &, 000 & \\
\hline & & $\mathrm{N}$ & 46 & 46 \\
\hline
\end{tabular}

The obtained result allowed us to reject the null hypothesis about the lack of interdependence between variables and to accept the alternative hypothesis about the existence of a connection.

\section{DISCUSSION}

The objective of this research was to translate and validate at the linguistic level the Ukrainian variant of the Gender Bias Quiz questionnaire. Following approved translation and linguistic verification methods, we sought to produce a Ukrainian translation variant of the tool, conceptually equal to the original. The Ukrainian variant of the Gender Bias Quiz appears to be a linguistically valid measure of gender bias among young people (students).

The application of Wilcoxon's statistical criterion did not reveal significant differences between the respondents' scores obtained on the basis of the English and Ukrainian versions of the Gender Bias Quiz questionnaire. This indicates that these two variants are equal at the linguistic level. Having identified monotonous positive correlations between the scores of the translated and initial variants of the tool, the null hypothesis was refused and the alternative hypothesis was confirmed. These results suggest that the Ukrainian variant of the Gender Bias Quiz questionnaire is semantically similar to the original English version of the tool.

The use of the questionnaire is important for psychological science. In Ukraine there has not been enough research that studied the gender biases of young people. Thus, the availability of this tool will allow psychologists to understand what biases are inherent in Ukrainian youth. It is necessary to mention that the data collected can be used in the development of educational and training courses on the prevention of gender discrimination.

The introduction of courses focused on respect for the individual and the reduction of gender stereotypes will allow the education system to be more democratic towards the participants of the educational process. We also see further prospects for the study in determining gender biases not only of student youth, but also of teachers and other employees in the educational institutions. Such a study will determine the level of gender bias in the higher education system of Ukraine, which is an important indicator for understanding the conditions for the introduction of gender equality.

It should also be noted that when studying gender issues (gender stereotypes, attitudes towards gender inequality, gender imbalance, etc.), it is important to combine methods that allow for both quantitative indicators (for example, the level of gender bias) and qualitative ones, which can be obtained through other methods, such as the method of content analysis [43, 44]. Therefore, we advise researchers who will use the Ukrainian-language version of the Gender Bias Quiz questionnaire to design their research plan in such a way that it also includes additional methods that would clarify the data obtained using the questionnaire.

\section{CONCLUSION}

According to the results of this study, it was determined that the Ukrainian version of the Gender Bias Quiz is linguistically equivalent to the English-language questionnaire. However, there are some boundaries of this study linked to the features of the respondents. Initially, the questionnaire was conducted on a small sample $(\mathrm{N}=46)$. Respondents were also mainly females $(\mathrm{N}=32)$. Therefore, it is recommended to crossvalidate the results of this study and comprehensive psychometric analysis on different Ukrainian student youth samples.

Further studies of the Gender Bias Quiz Ukrainian translated variant is currently undergoing a bigger representation of participants $(\mathrm{N}=220)$. The purpose of this study is to evaluate extensively the psychometric characteristics of the questionnaire. Such psychometric validation will allow using the method for the Ukrainian population. In addition, the English and Ukrainian versions of the Gender Bias Quiz questionnaire will allow a cross-cultural comparison of gender biases between Ukrainians and representatives of English-speaking countries (USA, UK, Canada, etc.). 


\section{AUTHORS' CONTRIBUTIONS}

T.K.: questionnaire translation procedure, collection and evaluation of the questionnaire, analysis of the data, wrote the manuscript, design of the research and statistical analysis of the data; D.D.: assistance in the statistical analysis of the data, advice on interpreting the results, I.B.: advice on the theoretical aspects related to the methodology of the experiment.

\section{ETHICS APPROVAL AND CONSENT TO PARTICIPATE}

The study was approved by the Institutional Review Board of the Department of Psychology, Social Work and Pedagogy V.I. Vernadsky Taurida National University (protocol code DPSWP/5-2019, date of approval 5 December 2019).

\section{HUMAN AND ANIMAL RIGHTS}

No animals were used in this research. All human research procedures followed were in accordance with the ethical standards of the committee responsible for human experimentation (institutional and national) and with the Helsinki Declaration of 1975, as revised in 2013.

\section{CONSENT FOR PUBLICATION}

Informed consent was obtained from all subjects involved in the study.

\section{AVAILABILITY OF DATA AND MATERIALS}

The authors confirm that the data supporting the findings of this research are available within the article.

\section{FUNDING}

None.

\section{CONFLICT OF INTEREST}

The authors declare no conflict of interest, financial or otherwise.

\section{ACKNOWLEDGEMENTS}

Declared none.

\section{REFERENCES}

[1] Gender equality and women's empowerment. Available from: https://www.un.org/sustainabledevelopment/gender-equality/

[2] The Shadow Pandemic: Violence against women during COVID-19. Available from: https://www.unwomen.org/en/news/in-focus/in-focus-gender-equalityi n-covid-19-response/violence-against-women-during-covid-19

[3] COVID-19 and violence against women. Available from: Www.who.inthttps://apps.who.int/iris/bitstream/handle/10665/331699/ WHO-SRH-20.04-eng.pdf?ua=1

[4] Policy brief: The impact of COVID-19 on women. Available from: https://www.un.org/sexualviolenceinconflict/wp-content/uploads/2020 /06/report/policy-brief-the-impact-of-covid-19-onwomen/policy-briefthe-impact-of-covid-19-on-women-en-1.pdf

[5] Whose time to care: Unpaid care and domestic work during COVID-19. Available from: https://data.unwomen.org/publications/whose-time-care-unpaid-care-a nd-domestic-work-during-covid-19

[6] Levant RF. Family psychology and the psychology of men and masculinities. J Fam Psychol 2017; 31(1): 2-4. [http://dx.doi.org/10.1037/fam0000289] [PMID: 28165278]
[7] Compendium of good practices for advancing women's political participation in the OSCE region. the OSCE Office for Democratic Institutions and Human Rights (ODIHR) 2016. Available from: https://www.osce.org/files/f/documents/8/1/224206.pdf

[8] The CS Gender 3000: The reward for change report from credit suisse research institute thought leadership from credit suisse research and the world's foremost experts 2016.https://investinginwomen.asia/knowledge/cs-gender-3000-reward -change/

[9] On International Women's Day. OSCE leaders call for strengthening women's leadership to achieve peace and security for all 2021. Available from: https://www.osce.org/chairmanship/480571

[10] Statement by Christine Lagarde at. Lifting the Small Boats", Grandes Conference Catholiques 2015. Available from: https://www.imf.org/en/News/Articles/2015/09/28/04/53/sp061715

[11] International Monetary Fund. Pursuing Women's Economic Empowerment. Available from: https://www.imf.org/en/Publications/Policy-Papers/Issues/2018/05/31/ pp053118pursuing-womens-economic-empowerment

[12] Norgaard K, York R. Gender equality and state environmentalism. Gender \& Society 2005; 19(4): 506-22.

[http://dx.doi.org/10.1177/0891243204273612]

[13] Austin K, Banashek C. Gender inequality and environmental wellbeing: A cross-national investigation of ecosystem vitality and environmental health. Sustain Environ 2018; 3(3): 257.

[http://dx.doi.org/10.22158/se.v3n3p257]

[14] $\mathrm{Ng}$ E, Muntaner C. The more women in government, the healthier a population. Available from: https://theconversation.com/the-more-women-in-government-the-healt hier-a-population-107075

[15] Allport G. Nature of prejudice. Cambridge, MA: Addison-Wesleu 1954.

[16] Bethlehem D. A social psychology of prejudice. London: Psychology Press 1985.

[17] Nelson TD. The psychology of prejudice. 2ND ed. Upper Saddle River, NJ: Pearson 2005.

[18] Jackson LM. The psychology of prejudice: From attitudes to social action. Washington, D.C., DC: American Psychological Association 2011.

[http://dx.doi.org/10.1037/12317-000]

[19] Whitley B, Kite M. Psychology of prejudice and discrimination. 3RD ed. Routledge 2016.

[20] Risman B. Raising the visibility of gender-nonconformists. Contexts (Berkeley Calif) 2017; 16(2): 72-4. [http://dx.doi.org/10.1177/1536504217714268]

[21] Martseniuk T. Gender for everyone challenging stereotypes. 2017.

[22] Riabov O, Riabova T. The remasculinization of russia? gender, nationalism, and the legitimation of power under vladimir putin. Probl Post-Communism 2014; 61(2): 23-35.

[http://dx.doi.org/10.2753/PPC1075-8216610202]

[23] Temkina A, Zdravomyslova E. Gender studies in post-soviet society: Western frames and cultural differences. Stud East Eur Thought 2003; 55(1): 51-61.

[http://dx.doi.org/10.1023/A:1021857831011]

[24] Rotkirch A, Temkina A, Zdravomyslova E. Who helps the degraded housewife? Comments on Vladimir Putin's demographic speech. Eur J Womens Stud 2007; 14(4): 349-57.

[http://dx.doi.org/10.1177/1350506807081884]

[25] Temkina A, Zdravomyslova E. Gender's crooked path: Feminism confronts Russian patriarchy. Curr Sociol 2014; 62(2): 253-70. [http://dx.doi.org/10.1177/0011392113515566]

[26] Sharipkin G. Is there gender equality in Belarus? 2020. Available from: https://cutt.ly/fnbeTn4

[27] Gürdeniz E, St-Onge E. AI has alarming power to spread gender bias Here are four ways to combat it. Available from: https://www.brinknews.com/ai-has-alarming-power-to-spread-genderbias-here-are-four-ways-to-combat-it/

[28] Anastasi A, Urbina S. Psychological testing: United States edition. 7th ed. Upper Saddle River, NJ: Pearson 1996.

[29] Bem SL. The measurement of psychological androgyny. J Consult Clin Psychol 1974; 42(2): 155-62.

[http://dx.doi.org/10.1037/h0036215] [PMID: 4823550]

[30] Auster CJ, Ohm S. Masculinity and femininity in contemporary American society: A reevaluation using the Bem Sex-Role Inventory. Sex Roles 2000; 43: 499-528.

[http://dx.doi.org/10.1023/A:1007119516728]

[31] Ferrer-Pérez VA. The measure of the masculinity-femininity construct 
today: Some reflections on the case of the Bem Sex Role Inventory. Rev Psicol Soc 2014; 29(1): 180-207.

[http://dx.doi.org/10.1080/02134748.2013.878569]

[32] Implicit Association Test (IAT). Available from: Www.projectimplicit.nethttps://implicit.harvard.edu/implicit/aboutus.h tml

[33] Gender Bias Quiz. The institutional scorecard for gender mainstreaming. Available from: oasis.col.orghttp://oasis.col.org/bitstream/handle/11599/1740/2015_C OL_Gender-Bias-Quiz.pdf? sequence $=3$ \&isAllowed $=y$

[34] Rosenzweig S. Psychodiagnosis: An introduction to the integration of tests in dynamic clinical practice. London: Grune \& Stratton 1949.

[35] ITC statement on the use of tests and other assessment instruments for research purposes. International test commission. Available from: www.InTestCom.orghttps://www.intestcom.org/files/statement_using _ tests_for_research.pdf

[36] Kline P. A handbook of test construction introduction to psychometric design. Routledge 2016.

[37] Maxwell JA. Qualitative research design: An interactive approach.
2ND ed. Thousand Oaks, CA: SAGE Publications 2005.

[38] Chis A, Copaci I, Rusu AS. Romanian translation and linguistic validation of the Children and Adolescent Social Support Scale (CASSS). JPER. 2017; 25(1a): 44-56. Available from: http://www.marianjournals.com/files/JPER_articles/JPER_special_issu e_2017/Chis_et_all_JPER_25_1a_44_56.pdf

[39] WHO. Process of translation and adaptation of instruments. 2010.https://www.who.int/substance_abuse/research_tools/translation/ en/

[40] Adapting tests. International test commission. Available from: https://www.intestcom.org/files/guideline_test_adaptation_2ed.pdf

[41] Nasledov DI. Nasledov DI Mathematical methods of psychological research Data analysis and interpretation. 2012.

[42] Burlachuk LF. Psychodiagnostics: Textbook for Universities. Peter 2006.

[43] Corder GW, Foreman DI. Nonparametric statistics: A step-by-step approach. 2nd ed. Nashville, TN: John Wiley \& Sons 2014.

[44] Allen M, Ed. The SAGE encyclopedia of communication research methods. Thousand Oaks, CA: SAGE Publications 2017. [http://dx.doi.org/10.4135/9781483381411]

\section{(C) 2021 Kostina et al.}

This is an open access article distributed under the terms of the Creative Commons Attribution 4.0 International Public License (CC-BY 4.0), a copy of which is available at: https://creativecommons.org/licenses/by/4.0/legalcode. This license permits unrestricted use, distribution, and reproduction in any medium, provided the original author and source are credited. 